\title{
Mitigating Agricultural Diffuse Pollution: Uncovering the Evidence Base of the Awareness-Behaviour-Water Quality Pathway
}

\author{
Murat Okumah ${ }^{1, * \mathbb{C}}$, Pippa J. Chapman ${ }^{2}$, Julia Martin-Ortega ${ }^{1}$ and Paula Novo ${ }^{3}$ \\ 1 Sustainability Research Institute, University of Leeds, Leeds LS2 9JT, UK; j.martinortega@leeds.ac.uk \\ 2 School of Geography, University of Leeds, Leeds LS2 9JT, UK; p.j.chapman@leeds.ac.uk \\ 3 Land Economy, Environment and Society Group, Scotland's Rural College (SRUC), Edinburgh EH9 3JG, UK; \\ paula.novo@sruc.ac.uk \\ * Correspondence: ee15sa@leeds.ac.uk
}

Received: 27 November 2018; Accepted: 21 December 2018; Published: 24 December 2018

\begin{abstract}
Diffuse water pollution from agriculture (DWPA) is a major environmental issue worldwide causing eutrophication, human health problems, increased water treatment costs and reducing the recreational potential of water bodies. In addition to penalties and provision of incentives, policy efforts are increasingly focusing on raising land managers' awareness regarding diffuse pollution under the expectation that this would influence behaviours and thus increase uptake of best management practices that would, in turn, improve water quality. Given the multimillion financial investments in these awareness-focused approaches, a good understanding of the awareness-behavioural change-water quality pathway is critical to set the basis for assessing the real potential of these policy interventions. We systematically review the evidence across the full pathway drawing on published peer-reviewed papers from both the social and natural sciences, with a focus on Europe and North America. Results indicate that there is no one study that looks at the pathway in full, evidencing the paucity of research on the topic. For the limited studies that focus on the different components of the pathway, we find mixed evidence for the relationship between awareness and behaviour, and behavioural change and water quality. Furthermore, complexity within the pathway (e.g., through the study of factors mediating and moderating such relationships) has hardly been addressed by the literature. An in-depth understanding and analysis of this complexity—-through an integrative model covering the entire pathway—could help in the design and implementation of effective policy strategies to encourage best land management practices and ultimately improve water quality.
\end{abstract}

Keywords: environmental knowledge; land management; pro-environmental behaviour; best management practice; water resource management; diffuse water pollution

\section{Introduction}

Diffuse water pollution from agriculture (DWPA) is a major environmental issue worldwide, causing eutrophication, human health problems, increased water treatment costs and reducing the recreational potential of water bodies [1-4]. In Europe for instance, diffuse agricultural pollution poses significant pressure on $38 \%$ of the region's water bodies [3]. As the pressure to increase food production globally augments, DWPA is likely to increase [3]. In their search for new strategies to tackle this problem, academics and policy makers have increasingly drawn their attention to understanding and influencing the behaviour of land managers over the past decade [5-7]. By addressing farmers' behaviours with respect to the adoption of best management practices (BMPs), it is expected that diffuse pollution at the catchment scale can be reduced $[5,8,9]$. 
Among other mechanisms (e.g., penalties, provision of incentives), one of the strategies towards changing land managers' behaviour has been the provision of advice and increasing awareness $[5,10,11]$. This has resulted in the development of novel awareness-focused approaches that represent a transition from top-down, punitive and narrow strategies to bottom-up, voluntary, collaborative and integrative ones [2,5,7,12-17]. This shift is as a result of the failure of earlier approaches to significantly tackle DPWA due to its complexities (e.g., DPWA has an emergent character, several causal factors with multiple stakeholders). These novel approaches are expected to enable policy-makers and catchment managers to tap into land managers' (and other stakeholders') knowledge regarding their farm environments and socio-ecological systems to understand the "why" and "how" to achieve better outcomes $[13,14,17,18]$. Notably, catchment-based approaches (CaBA) - also referred to as integrated catchment and watershed management programmes—are being used in Europe and North America to provide advice to farmers through various participatory means [12-14,17,19-23]. It is expected that such dialogical approaches increase land managers' awareness of diffuse pollution and mitigation measures, leading to changes in behaviour that would reflect in the adoption of best land management practices and ultimately in water quality improvement $[13,14,17,18]$. Awareness refers to land mangers' consciousness of DWPA, mitigation measures, and/or associated consequences of (not) taking up such measures.

The cornerstone of these expectations is the assumption that a relatively straightforward link between awareness, behaviour and improvement in water quality can be established, but there is not yet a comprehensive review of the evidence to support this. The few existing reviews on this topic $[8,24]$ have only covered individual links between awareness and behaviour and behavioural change and water quality, but not the pathway in full. For example, Baumgart-Getz et al. focused on factors that affect adoption of BMPs without looking at their impact on water quality [24]. On the other hand, Kay et al. focused on whether the implementation of BMPs led to an improvement in water quality, without consideration of whether and how awareness affect land managers' adoption of those practices [8]. Given that land managers' attitudes and behaviours are fundamental antecedents of environmental quality and change [25], we would argue that partial understanding of this pathway is going to fall short of providing the comprehensive understanding that is needed for effective policy designs. Considering the multimillion financial investments in these awareness-focused approaches [14], a good understanding of the awareness-behavioural change-water quality pathway is thus critical to set the basis for assessing the real potential of these policy interventions.

This improved understanding of the awareness-behavioural change-water quality pathway could help assess the effects of awareness-focused interventions as well as allow stakeholders to adjust policy strategies to help reverse increasing pollution of water bodies within local contexts [26]. We contribute to addressing this knowledge gap by systematically reviewing the evidence base of awareness-behavioural change-water quality pathway in full, with a regional focus (Europe and North America). The added value of this study therefore lies in its ability to uncover the full pathway and, unlike earlier reviews, cutting across the natural and social sciences. Specifically, the study seeks to answer the following questions: (1) What is the evidence base of the awareness-behaviour-water quality pathway? (2) Based on this evidence, can we establish which factors (referred to as mediators and moderators) affect or could affect the complex relationships within this pathway? and (3) Which aspects of the full pathway and which variables have received little or no attention and what does it say of our current ability to develop strategies to mitigate diffuse pollution from agriculture?

\section{Methodology}

We employed a systematic review method to evaluate and synthesize the evidence linking awareness, behavioural change and improvement in water quality $[27,28]$. This was done as a structured and iterative process in four phases. In Phase 1, data search and extraction included an online search for papers. This involved the application of clearly defined search terms to access publications from the following academic sources: Google Scholar, Web of Science, Scopus, the Applied 
Social Sciences Index and Abstracts and Sociological Abstracts. Search terms covered the areas of environmental knowledge and awareness, behaviour, and water quality change as indicated in Table 1 (see Appendix A for an explanation on how the search items were applied). We restricted our search to documents published in English and within the last three decades (from 1987) because many contemporary diffuse pollution management policies and monitoring networks either commenced, became more consolidated or gained prominence around that time $[8,9,21,29,30]$. The final process in the literature search involved a snowball technique of manually tracing references from recent papers (e.g., $[8,9,21,26])$. This process yielded a total of 609 papers.

In Phase 2, references were filtered to remove duplicates, resulting in a total of 492 papers. In Phase 3 papers were screened to select those relevant to this study. To do this we read the titles, abstracts and the methodology section and applied the following inclusion criteria: reported the results of an empirical research, focused on the role of information or advice on uptake of diffuse pollution mitigation measures and/or water quality. After this stage, a substantial number of papers were excluded $(n=456)$, resulting in 36 published papers. The 456 papers were excluded for either being a review paper (e.g., $[5,8,10,19,24])$, providing conceptual overview of integrated catchment management approaches (e.g., $[15,18])$ or not focused on any of the components of the pathway. Here, empirical research refers to evidence from scientific testing or observation as opposed to speculation, hypothetical modelling or anecdotal information. We selected empirical papers because the study aimed at providing the evidence base of the awareness-behaviour-water quality pathway thus, the need for 'reliable information' as opposed to speculations, anecdotal data, or papers providing conceptual overview.

Next, we retained only papers that were based on observation and from North America or Europe. Our reason for retaining only papers from these regions was to analyse papers from similar farming and policy settings, and which covered a region in which catchment-based approaches and awareness-oriented strategies are being clearly articulated and promoted $[13,14,17,19,21,31]$. Only 19 papers met all of the criteria outlined above and form the basis of this review (see Table A1 for an overview of these papers).

The fourth and final phase involved reading all of the 19 papers and extracting data relevant to the three research questions. A deductive approach was employed to analyse the evidence in relation to the three research questions: (1) what is the evidence base of the awareness-behaviour-water quality pathway? (2) Which factors affect or could affect this pathway? (3) Which aspects of the full pathway and which variables have received little or no attention? The approach offers the possibility to expound underlying connections between models and variables and the opportunity to take a broad view of research findings. The papers were evaluated critically for key results, with the aim of identifying the presence of an observed relationship between variables (which could be direct or indirect and/or positive, negative or mixed) or whether there was no evidence of a relationship.

Next, we checked whether authors reported psychosocial and biophysical variables (referred to as mediators and morderators (Mediators are variables through which an independent variable (e.g. awareness) transmits its effects onto a dependent variable (e.g. water quality) while moderators are those elements that contingently influence the statistical significance, direction and/or strength of the relationship between two or more other variables (e.g. awareness, behaviour and water quality).)) that affect or could affect the relationships under study. This is because the literature on environmental psychology, land management and environmental biogeochemistry have highlighted that some variables could affect the relationship between awareness and behaviour and behaviour and water quality. For instance, even when a farmer is aware of diffuse pollution mitigation measures, uptake of such measures is not guaranteed as this depends on e.g., farm type, scheme design, financial cost and time required to implement such mitigation measures [32-34]. Similarly, even when farmers implement the required mitigation measures, improvement in water quality is not guaranteed as this depends on e.g., land use type and intensity, pollutant type, crop uptake of nutrients, and for groundwater, this depends very much on the depth of the aquifer $[21,26,35,36]$. Investigating the interaction between these factors and the awareness-behaviour-water quality pathway is expected to enhance our understanding. 
Table 1. Compilation of search terms.

\begin{tabular}{ll}
\hline \multicolumn{1}{c}{ Group } & \multicolumn{1}{c}{ Search Terms } \\
\hline \multirow{3}{*}{$\begin{array}{l}\text { 1. Environmental knowledge } \\
\text { and awareness }\end{array}$} & $\begin{array}{l}\text { Advice; Agricultural Stewardship; Agrienvironmental Scheme; Appreciation; } \\
\text { Consciousness; Awareness Campaign; Awareness; Environmental Concern; Environmental } \\
\text { Education, Environmental Stewardship; Information; Intervention Programme; } \\
\text { Knowledge; Recognition; Understanding }\end{array}$ \\
\hline \multirow{2}{*}{ 2. Behaviour } & Act; Adoption; Apply; Carry Out; Compliance; Conform; Effect; Engage; Execute; \\
& Implementation; Perform; Practise; Uptake \\
\hline & Agricultural Change; Best Management Practice; Catchment Management; Catchment \\
& Sensitive Farming; Conservation; Diffuse Pollution Management; Diffuse Pollution \\
& Mitigation; Farm Management Practices; Farm Practices; Hydrologically Sensitive Area \\
& Measures; Land Quality Sustenance; Land Resource Management; Land Resource Use; \\
& Land Use Control; Land Use Pattern; River Basin Management; River Management; Soil \\
& Conservation; Soil Management; Sustainable Agriculture; Sustainable Farming Activities; \\
& Water Resource Management; Watershed Management \\
3. Land management & Agricultural River; Agricultural Runoff; Aquatic Ecosystem; Contamination Potential \\
& Index; Deposition Flux; Ecological Condition of Water; Ecological Status of Water; \\
& Groundwater Quality; Marine Eutrophication; Nitrate; Soil Water Retention; Nitrate; \\
& Nitrogen Deposition; Nitrogen Deposits; Nutrient Leakage; Nutrient Pollution; Pesticide \\
& concentration; Phosphate; Phosphorus Deposition; Phosphorus Exportation; Pollutant \\
& Concentration; Pollutant Load; Reduced Nutrient; River Water Chemistry; Riverine Loads; \\
& Stream Health; Stream Integrity; Stream Purification; Stream Water Quality; Surface Water \\
Quality; Water Quality Assessment; Water Quality Improvement; Water Quality Index; & Water Regulation Capacity; Watershed Hydrology; Sediment \\
\hline \multirow{3}{*}{ 4.Water quality and } &
\end{tabular}

\section{Results and Discussion}

\subsection{Overview of the Evidence}

The 19 papers selected for the purpose of this study span both the social and natural sciences (Table A1). Nine papers covered the behavioural change-water quality link, nine covered the awareness-behaviour link, and one paper covered the awareness-water quality link. None of the papers explored the full awareness-behavioural change-water quality pathway.

Figure 1 and Table A2 provide information on potential mediators and moderators of the awareness-behavioural change-water quality pathway. From Figure 1, it is clear that some variables (e.g., situational factors) have received substantial attention in the academic literature, while others (e.g., moral norms) have received much less attention. Situational factors are extrinsic factors that facilitate or constrain farmers' environmental behaviour and water quality responses. These may include institutional support (or lack of), farm size, farm type, farm tenure, income, cost of materials/compliance, 'goodness of fit' of schemes, flexibility of schemes, and variant of pollutant, among others. Of the 26 potential mediators and moderators, 14 of them are psychosocial factors (e.g., social norm, attitude, habit) mainly associated with awareness and behaviour. Eleven of these variables are biophysical factors (e.g., pollutant type, critical source of pollution) with direct implications for water quality, while the last variable (situational factors) affects both awareness and behaviour, and water quality. 


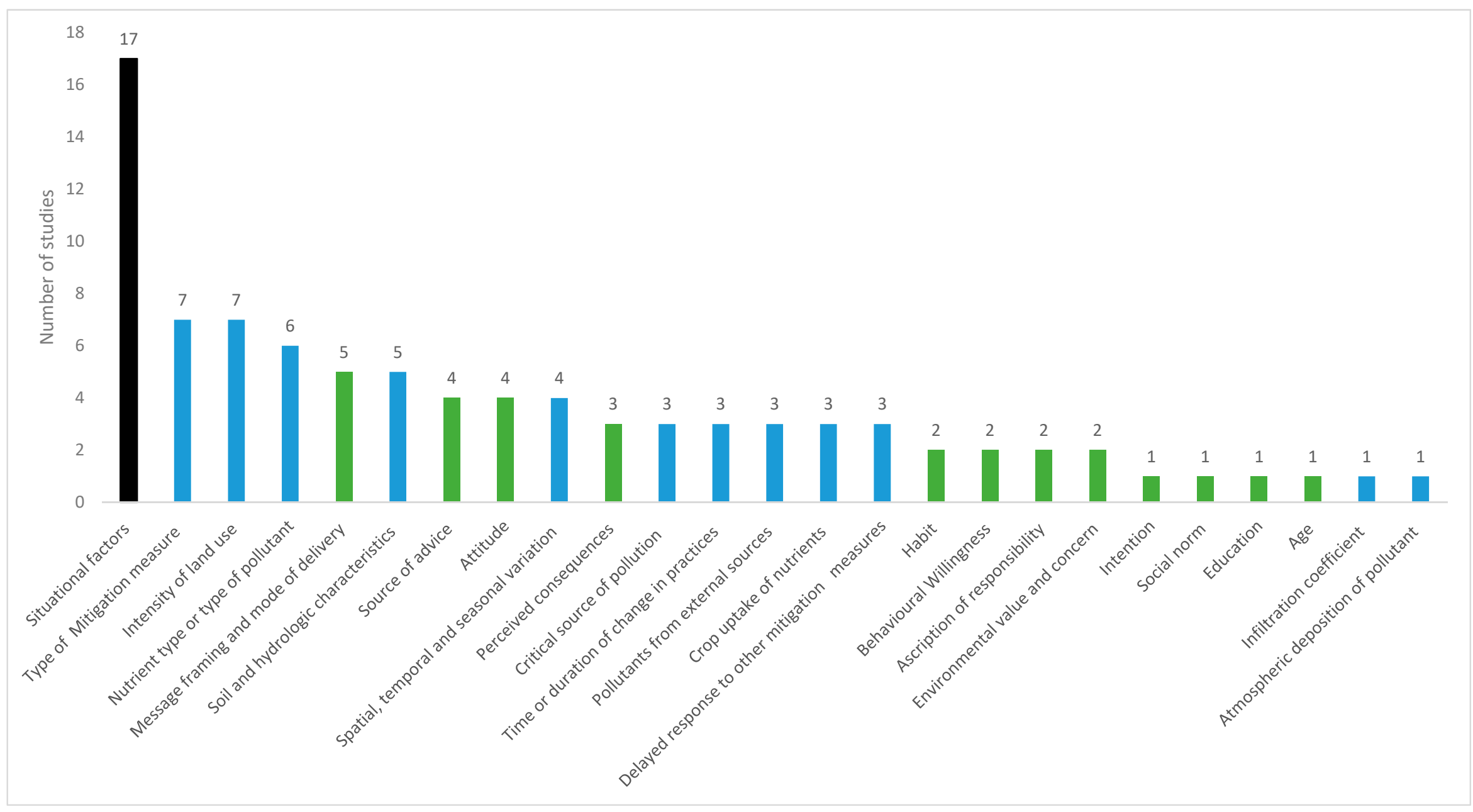

Figure 1. Summary of variables affecting the awareness-behavioural change-water quality pathway. Note: Green = factors directly affecting awareness and behaviour; Blue = factors directly affecting water quality; Black = factor affecting awareness, behaviour and water quality. 


\subsection{Uncovering the Evidence-Base of the Awareness-Behaviour-Water Quality Pathway}

In this section, we classify the evidence under the following components of the pathway: (i) awareness-behaviour change link; (ii) awareness-water quality link; (iii) behavioural change-water quality link; and (iv) the full awareness-behaviour-water quality pathway.

\subsubsection{Awareness-Behavioural Change Link}

Almost all studies that reported on a direct relationship between awareness and behavioural change $(n=7)$ indicate a positive effect with the exception of Barnes et al. and Macgregor and Warren who reported negative attitudes, lack of ascription of responsibility to self and unchanged behaviours despite the implementation of awareness campaigns and participation in schemes [33,34]. Two studies found a positive indirect effect through the mediating effect of agricultural stewardship [11,37]. That is, awareness affected participation in agricultural stewardship schemes and this in turn affected willingness and compliance with best land management practices.

Table 2 shows diffuse pollution mitigation measures and associated outcomes, as well as other variables that affect the awareness-behavioural change link. Results suggest that the relationship is influenced by a range of factors such as farm size, farm type, farm tenure, cost of materials/compliance, 'goodness of fit' of schemes, flexibility of schemes (see also Figure 1 and Table A2). Seven studies reported situational factors that affect this relationship [11,32], while social norm and intention were the least reported (only one study). Additionally, evidence shows that awareness itself may be dependent on sociodemographic characteristics (e.g., age, education level and gender), environmental values, concern and beliefs, thus, better access to information does not guarantee an increase awareness for the DWPA [38].

The idea that situational factors influence behaviours has been established in the literature, e.g., in Stern's Attitude-Behaviour-Context model which postulates that the link between attitude and behaviour is dependent on situational factors [39]. Thus, where situational factors play a weak role, the direct link between attitude and behaviour is strong while this direct link weakens where the role of situational factors is strong. This is in line with the findings of some of the studies reviewed in this paper e.g., Macgregor and Warren, and Barnes et al. who found that attitudes and behaviours did not change despite awareness of the Nitrate Vulnerable Zones (NVZ) scheme (attributable to the inflexible nature of schemes, time and financial cost of compliance) [33,34]. The inflexible nature of schemes makes it often harder for farmers to respond to changes in markets thus even if advice is good, the scheme may not be flexible enough to allow uptake of BMPs-highlighting the crucial role of situational factors (e.g., scheme content and design). Overlooking these factors weakens the analysis and understanding of the awareness-behaviour link. This in turn limits our ability to design policies that can be adapted to various contexts or situations.

Although other potential moderators (e.g., source of advice, message framing and means of delivery) have not been widely studied and reported in the diffuse pollution management literature, they play a key role and need to be considered in policy designs. For instance, the limited research in this field has indicated that the source of information (i.e., the institution that is sending the information and/or the farm advisor) is a crucial factor determining whether land managers take up best land management measures or not, especially where the message is well-placed, consistent and well framed [40-42]. Additionally, uptake across catchment might be influenced by social norms, that is, farmers are more likely to take up BMPs where their neighbours adopt such practices and the practices become embedded in their norms [43,44]. 
Table 2. Effects of awareness on behaviour via uptake of diffuse pollution mitigation measures.

\begin{tabular}{|c|c|c|c|c|c|c|}
\hline Link & $\begin{array}{c}\text { Diffuse Pollution } \\
\text { Mitigation Measure(s) }\end{array}$ & Results & Other Influential Factors & Method & $\begin{array}{l}\text { Number of } \\
\text { Respondents }\end{array}$ & Reference \\
\hline \multirow{4}{*}{ Direct relationship } & $\begin{array}{l}\text { Advice on general } \\
\text { conservation/biodiversity } \\
\text { management }\end{array}$ & $59 \%$ adopted scheme measures. & $\begin{array}{l}\text { Scheme design or package, farm } \\
\text { system and income sources. }\end{array}$ & Survey and statistical test & 144 & [32] \\
\hline & $\begin{array}{l}\text { General BMPs for farms and } \\
\text { diffuse pollution advice }\end{array}$ & Awareness affects adoption $(p \leq 0.05)$. & $\begin{array}{l}\text { Belief, farm tenancy, access to } \\
\text { equipment, farm size, and trust in } \\
\text { source of advice. }\end{array}$ & $\begin{array}{l}\text { Surveys, open interviews, focus } \\
\text { groups and statistical analysis }\end{array}$ & $\begin{array}{c}145 \\
1320 \\
30^{*} \\
\end{array}$ & $\begin{array}{l}{[45]} \\
{[46]} \\
{[23]}\end{array}$ \\
\hline & $\begin{array}{l}\text { Nutrient management, filter } \\
\text { strips, and streambank fencing }\end{array}$ & $\begin{array}{l}\text { Those who were aware of nutrient management regulations were } 28 \% \\
\text { more likely to adopt nutrient management as a BMP, and was found } \\
\text { to increase filter strip adoption by } 24 \% \text {. }\end{array}$ & $\begin{array}{l}\text { Business ownership, years } \\
\text { anticipated to remain in business, } \\
\text { education, cost/benefit. }\end{array}$ & Survey and statistical test & 150 & [22] \\
\hline & NVZ-related advice & $\begin{array}{l}\text { Despite awareness of the NVZ regulations, farmer attitudes indicate a } \\
\text { somewhat negative view towards the perceived environmental } \\
\text { benefits, water management and behaviours have not changed. }\end{array}$ & $\begin{array}{l}\text { Ascription of responsibility, attitudes } \\
\text { and inflexible nature of regulations }\end{array}$ & $\begin{array}{l}\text { Survey, workshops, interviews } \\
\text { and statistical analysis }\end{array}$ & $\begin{array}{l}184 \\
30^{*}\end{array}$ & {$[33,34]$} \\
\hline Indirect relationship & $\begin{array}{l}\text { Diffuse pollution measures to } \\
\text { protect water quality }\end{array}$ & $\begin{array}{l}\text { Awareness influenced willingness }(p \leq 0.05) \text { to adopt as well as } \\
\text { adoption/compliance }(p \leq 0.1) \text { indirectly through the mediating effect } \\
\text { of agricultural stewardship. } 46.2 \% \text { complied with regulations. }\end{array}$ & Farm type and location. & Survey and statistical test & $\begin{array}{c}647 \\
1564\end{array}$ & {$[11,37]$} \\
\hline
\end{tabular}

For number of respondents, * indicates number for qualitative interviews; all others are surveys. Number of respondents follow a respective order where there are two or more references. 


\subsubsection{Awareness and Water Quality Link}

This was the least studied link in the awareness-behaviour-water quality pathway, with only one study found in the literature. Kreuger and Nilsson found that Swedish aquatic ecosystems underwent remarkable (more than 90\%) reductions in concentrations of pesticides in catchments where farmers received catchment specific information regarding best pesticide management practices [47]. Based on expert judgement and qualitative reasoning, they attribute this to an improvement in land management owing to awareness of BMPs regarding handling of spraying equipment and application procedures. However a clear link between both awareness and water quality is still missing. Further research is thus required to exploring how awareness translates into water quality improvements, what's the role of other influential factors such as farmer attitude, behaviours, and biogeochemical changes and ultimately what's the effectiveness of awareness centred approaches.

\subsubsection{Behavioural Change and Water Quality Nexus}

The nine papers reviewed found contrasting evidence for a relationship between uptake of mitigation measures and improvements in water quality (Table 3). Four papers found a positive effect, and five reported mixed results i.e., positive effect in some (sub) catchments, negative results in others and no changes in some others. Eight papers reported variation in results for different pollutants while five (of those eight papers) reported variation across (sub) catchments. For instance, Kay et al. reported a decline in nitrate concentrations in 7 of the 10 sub-catchments studied and that there was no decrease in phosphorus in any of the sub-catchments [9]. They attributed this variation to a number of potential factors such as time lag and the fact that these pollutants derive from other sources than just agriculture. This means that even when farmers take up mitigation measures, the impact on pollutant concentration and/or loads (and by extension, water quality) depends very much on the type of pollutant. For example, in the case of phosphorus, research has shown that the impact on concentrations may take longer to be realised due to the build-up of phosphorus in soils and river sediments-raising concerns about time lags $[13,14,48-50]$. In catchments dominated by groundwater, nitrate usually moves slowly through the aquifer. Thus it can take several decades to reach rivers and so the impacts of land management actions (e.g., reduced fertiliser application) may not be evident for many years [49]. As Kay et al. noted, the decline in nitrate concentration observed in some sub catchments could be due to delayed impacts of the implementation of NVZs [9]. Such temporal and spatial mismatches may affect a direct relationship being observed in the short-term between behavioural change and improvements in water quality.

We also found that the variation in results across (sub) catchments could also be attributed to different levels of uptake by land managers across catchments and the focus of mitigation measures (e.g., $[8,9,51])$ which may be difficult to determine at the broader catchment scale. That is, farmers in some (sub) catchments may not implement the recommended measures and the measures implemented may vary in terms of focus: some farmers may adopt mitigation measures that are more focused on reducing nitrate leaching to water bodies as opposed to mitigation measures that are more focused on phosphorus. For instance, if farmers implement manure focused mitigation measures, this could result in little or no reduction in other pollutants e.g., sediments [51]. However, if the mitigation measure focuses on reducing soil erosion, it is more likely that significant reduction in sediments will be realised [51]. This complex interaction between type of mitigation measures and uptake of measures needs to be more critically considered at the catchment scale to assess effectiveness of mitigation measures.

Again, biophysical factors such as the geological and climatic characteristics of the land affect the impact of behavioural changes on water quality $[21,26,52,53]$. For instance, if farmers in two different catchments take up the same mitigation measures on their farms, improvement in water quality is likely to be lower in a catchment with high runoff. Ryberg et al. use structural equation modelling to show how these factors including climate variability and anthropogenic factors interact in a complex manner to determine phosphorus loads—a key measure of water quality—in the Chesapeake 
Bay watershed [54]. They found that while purposeful management practices help in decreasing phosphorus loading in the watershed, the effects are counterbalanced by increasing runoff attributed to natural climate variability.

Other factors that may play a role include differences in land use, crop uptake of nutrients, and for groundwater, this depends very much on the depth of the aquifer $[21,26,35,36]$. Additionally, the intensity of land use may affect pollutant loads in water resources although reduced production and/or productivity levels do not always result in significant reduction of agricultural pollutants in water bodies [55]. Moreover, some land units may be critical sources of diffuse pollution than others $[9,26]$. This is related to hydrologically sensitive areas (i.e., the portion of land within the catchment which contributes actively to runoff) and critical source area (that is, the portion of land within the catchment where large amounts of pollutants are generated) that may serve as explanatory variables to water quality responses [26]. For instance, Thompson et al. found that arable soils produced more suspended sediment than grassland and woodland in some catchments [56]. 
Table 3. Effects of uptake of mitigation measures on water quality.

\begin{tabular}{|c|c|c|c|c|}
\hline Pollutant & Mitigation Measure(s) & Results & Other Influential Factors & Reference \\
\hline \multirow{7}{*}{ Nitrate } & $\begin{array}{l}\text { Implementation of the Code of Good Agricultural Practice and } \\
\text { measures in Nitrate Vulnerable Zones (NVZ). }\end{array}$ & $\begin{array}{l}\text { Nitrate concentrations decreased significantly in } 7 \text { out of } 10 \text { sub catchments. } \\
\text { The median nitrate concentration reduced from } 3.7 \mathrm{mg} \mathrm{N} \mathrm{L}-1 \text { before implementation to } \\
2.7 \mathrm{mg} \mathrm{N} \mathrm{L}^{-1} \text { after implementation (study conducted between } 2006 \text { and } 2009 \text { ). }\end{array}$ & $\begin{array}{l}\text { Time lag i.e., delayed benefits of NVZ actions (as } \\
\text { this started in 2002). }\end{array}$ & [9] \\
\hline & $\begin{array}{l}\text { Reduction in the percentages of arable crops, lower } \mathrm{N} \text { fertiliser use in } \\
\text { arable farming, greater extent of cover cropping, grassland with little } \\
\text { or no } \mathrm{N} \text { fertilisation. }\end{array}$ & $\begin{array}{l}\text { Nitrate content reduced by } 3.2 \mathrm{mg} \mathrm{L}^{-1} \text {, with up to }-4.4 \mathrm{mg} \mathrm{L}^{-1} \text { observed in some areas. } \\
\text { Mean reduction in N leaching of } 29 \%\left(16 \mathrm{~kg} \mathrm{~N} \mathrm{ha}^{-1} \text { year }^{-1}\right) \text { for the arable land in the } \\
\text { Fehraltorf catchment. }\end{array}$ & $\begin{array}{l}\text { Soil and hydrological characteristics, type of } \\
\text { mitigation measure and critical source, scale } \\
\text { of analysis. }\end{array}$ & [57] \\
\hline & $\begin{array}{l}\text { Implementation of the Code of Good Agricultural Practice, spatial } \\
\text { and temporal restrictions for use of fertilisers, buffer strips along the } \\
\text { water courses, protection zones around the wells, etc. }\end{array}$ & $\begin{array}{l}\text { No significant changes in concentration was observed except for an increase in one river } \\
\text { (the River Ra"pu). For ground water, recent (since 2003) results indicate a slight increase } \\
\text { in nitrate content in those areas with more intensive agriculture. }\end{array}$ & $\begin{array}{l}\text { Land use intensity, soil and hydrological } \\
\text { characteristics, and how long measure } \\
\text { was implemented. }\end{array}$ & [21] \\
\hline & $\begin{array}{l}\text { Use of buffer strips (For a more detailed review of nutrient efficacies } \\
\text { of buffer zones, see Kay et al. (2009).) }\end{array}$ & $\begin{array}{l}\text { No statistically significant differences were observed (at } \mathrm{P}>0.05 \text { ) between buffer strip (BS) } \\
\text { and no buffer strip (no-BS). Nutrient removal efficiency: } 9 \% \text { decrease-217\% increase }\end{array}$ & $\begin{array}{l}\text { Spatial and seasonal variation, soil and } \\
\text { hydrological characteristics. }\end{array}$ & [58] \\
\hline & $\begin{array}{l}\text { Buffer strips (BS) A fertilization rate reduction by } 15 \% \text { and } 30 \% \mathrm{BS} \text {, } \\
\text { fertilizer reduction, Pasture land increase and other BMPs. }\end{array}$ & $\begin{array}{l}\text { A reduction of } 3.9-9.3 \% \text { in nitrate load depending on width of BS } 15.1 \% \text { and } 25 \% \\
\text { reduction respectively in nitrate loads4.7-38.2\% reduction in nitrate loads; results } \\
\text { varied across seasons. }\end{array}$ & $\begin{array}{l}\text { Land use intensity and how long measure } \\
\text { was implemented. }\end{array}$ & [59] \\
\hline & Reduce fertilizer application & $\begin{array}{l}\text { Land with nitrate concentrations exceeding } 50 \mathrm{mg} \mathrm{L}^{-1} \text { observed } 13-33 \% \text { reduction but } \\
\text { results vary across different variants of } \mathrm{N} \text {. Nitrate leaching decreased by } 0.08 \mathrm{~kg} \mathrm{ha}^{-1} \\
\text { year } \\
\text { differed ach the net } \mathrm{N} \text { loading of the soil decreased by } 1 \mathrm{~kg} \mathrm{ha}^{-1} \text { year }^{-1} \text {, but results } \\
\text { exceeding } 100 \mathrm{mg} \mathrm{L}^{-1} \text { decreased from } 1 \%-17 \% \text { depending on the variant of } \mathrm{N} \text {. }\end{array}$ & $\begin{array}{l}\text { Pollutant type, type of mitigation measure, spatial } \\
\text { and seasonal variation, land use intensity, } \\
\text { how long measure was implemented, external } \\
\text { sources, crop uptake of nutrients. }\end{array}$ & [60] \\
\hline & NVZ regulations & $\begin{array}{l}\text { 29\% of NVZs showed a significant improvement but } 31 \% \text { showed a significant } \\
\text { worsening. The average improvement relative to a control due to NVZ designation was } \\
0.02 \pm 0.08 \mathrm{mg} \mathrm{N} \mathrm{L}^{-1} \text { year }\end{array}$ & $\begin{array}{l}\text { Type of mitigation measure, soil and hydrological } \\
\text { characteristics, land use intensity. }\end{array}$ & [61] \\
\hline \multirow{4}{*}{ Total $\mathbf{N}$} & $\begin{array}{l}\text { Implementation of the Code of Good Agricultural Practice, spatial } \\
\text { and temporal restrictions for use of fertilisers, buffer strips along the } \\
\text { water courses, protection zones around the wells, etc. }\end{array}$ & A statistically significant decreasing trend in TN was observed in the River Po Itsamaa & $\begin{array}{l}\text { Pollutant type, type of mitigation measure, critical } \\
\text { source, spatial and seasonal variation, soil and } \\
\text { hydrological characteristics and external sources. }\end{array}$ & [21] \\
\hline & $\begin{array}{l}\text { Reduced autumn ploughed area between } 7 \% \text { and } 17 \% \text {, introduction } \\
\text { of catch crop and constructed wetlands. }\end{array}$ & $\begin{array}{l}\text { Non-statistically significant downward trend observed ( } p \text {-value } \geq 0.05 \text { ), though some } \\
\text { catchments show a decline or an increase in absolute values. }\end{array}$ & $\begin{array}{l}\text { Differences in crop type, land use intensity, } \\
\text { fertilizer application and delay in uptake of } \\
\text { measures in some catchments. Intensity of } \\
\text { advisory services and financial support varied. }\end{array}$ & [62] \\
\hline & Use of buffer strips & $\begin{array}{l}\text { Reducing total nitrogen losses from } 17.3 \text { to } 4.5 \mathrm{~kg} \mathrm{ha}^{-1} \text { in terms of mass balance. } \\
\text { Nutrient removal efficiency: } 10 \% \text { decrease-2} 217 \% \text { increase }\end{array}$ & $\begin{array}{l}\text { Spatial and seasonal variation, soil and } \\
\text { hydrological characteristics. }\end{array}$ & [58] \\
\hline & Tramline management & $74-98 \%$ reduction in what total $\mathrm{N}$ & $\begin{array}{l}\text { Pollutant type, type of mitigation measure, spatial, } \\
\text { temporal and seasonal variation. }\end{array}$ & [63] \\
\hline
\end{tabular}


Table 3. Cont

Pollutant

\section{Mitigation Measure(s)}

lacement of in-field manure heaps, soil and manure nutrient content analysis, leaving buffer zones next to water courses when spreading mantre and reseeding grassland, installing stream fencing to exclude livestock.

Reduction in the percentages of arable crops, Lower $\mathrm{N}$ fertiliser use little or no $\mathrm{N}$ fertilisation.

Results

Remained relatively static except for 1 monitoring site where a reduction was observed, Probably due to some farmers not engaging and others implementing particular measures only.

The $P$ pollution of Swiss surface waters from farm systems reduced by between $10 \%$ nd a maximum of $30 \%$

Soil and hydrological characteristics, type mitigation measure and critical source.

Reduced autumn ploughed area between $7 \%$ and $17 \%$, introduction Nonstatistically significant downward trend observed $(p$-value $\geq 0.05)$ though some of catch crop and constructed wetlands. Nonstatistically significant downward trend

Differences in crop type, type of mitigation

characteristics, how long measure was mplemented, intensity of advisory services, leve of financial support.

\begin{tabular}{|c|c|c|c|}
\hline & & 11 & \\
\hline Use of buffer strips & $27 \%$ reduction $-41 \%$ increase in total $P$ & $\begin{array}{l}\text { Spatial and seasonal variation, soil and } \\
\text { hydrological characteristics. }\end{array}$ & {$[58]$} \\
\hline Tramline management & $72-99 \%$ reduction in total P & $\begin{array}{l}\text { Type of mitigation measure, spatial, temporal and } \\
\text { seasonal variation. }\end{array}$ & [63] \\
\hline Reduce fertilizer application & $\begin{array}{l}\text { Reduction in P leaching to surface waters was much less than } 0.1 \mathrm{~kg} \mathrm{ha}^{-1} \text { when the net } \\
\text { P loading of the soil diminished by } 1 \mathrm{~kg} \mathrm{ha}^{-1} \text { (mainly because } \mathrm{P} \text { is strongly retained by } \\
\text { the soil). }\end{array}$ & $\begin{array}{l}\text { Type of mitigation measure, spatial and seasonal } \\
\text { variation, land use intensity, how long measure } \\
\text { was implemented, external sources, crop uptake } \\
\text { of nutrients. }\end{array}$ & [60] \\
\hline
\end{tabular}
Placement of in-field manure heaps, soil and manure nutrient content
analysis, leaving buffer zones next to water courses when spreading Remained relatively static except for 1 monitoring site where a reduction was observed, Possibility of external sources of pollutants $\begin{array}{ll}\text { manure and reseeding grassland, installing stream fencing to } & \text { with the } p \text {-value of regression analysis being significant. } \\ \text { exclude livestock } & \end{array}$ e.g., Boron.

No significant trends in $\mathrm{P}$ concentrations in agricultural rivers since the 1990s except for Implementation of the Code of Good Agricultural Practice, spatiaa water courses, protection zones around the wells, etc. an increase in the River Ra" $\mathrm{p}$ Farm type, land use intensity and external sources of pollutants.

No significant differences in total $\mathrm{P}$ concentrations between $\mathrm{BS}$ and no-BS but the median reduction (almost $22 \%$ ) became significant $(\mathrm{P}<0.05)$. Nutrient removal

Spatial and seasonal variation, soil and hydrological characteristics.

Use of buffer strips efficiency: $17 \%$ decrease- $-475 \%$ increase

Differences in crop type, land use intensity

fertilizer application and delay in uptake

Reduced autumn ploughed area between $7 \%$ and $17 \%$, introduction Non-statistically significant downward trend for some catchments, but one catchment shows a statistically significant upward trend $(p$-value $\leq 0.05)$

intensity of advisory services and

Sediment

Use of buffer strips

$78 \%$ reduction in sediment losses

Tramline management

75-99\% reduction in sediment losses 


\subsubsection{Awareness-Behaviour-Water Quality Pathway}

We did not find any primary study in the academic literature that investigates the full awareness-behaviour-water quality pathway, although researchers often tried to link these variables using correlation analysis, qualitative inferences and/or expert judgement (e.g., [9]). As such, there is currently a lack of evidence on the hypothesis that land managers who are aware of diffuse pollution and mitigation measures are more likely to take up these measures and this, in turn, may result in improvements in water quality.

Additionally, none of the studies reviewed in this study considered the joint effect of psychosocial and biophysical factors on land management and water quality. While existing studies examined the factors that can potentially affect awareness and adoption of diffuse pollution mitigation measures, the mechanisms and the conditions under which this happens (i.e., the relevant mediators and moderators) and whether some of these factors are confounding variables remain understudied. However, when these variables are considered in first generation statistical techniques (e.g., correlations, multiple regressions), they are found to have an influence on awareness and/or adoption of mitigation measures (e.g., [64-66]). These findings point to the need for developing more sophisticated analysis that takes into account the complex nature of catchments, pro-environmental behaviour and diffuse agricultural water pollution [11,15,25]. Knowledge of the mechanisms and interactions between awareness and these variables can help to design more targeted and effective land use policies [10,54].

We now turn to discuss potential limitations of our study. For instance, although the strategy adopted in the data gathering process, a multi-pronged method enhances precision and recall rates [67], there is a danger that a few studies are missed if they do not contain the search terms in their titles, keywords and abstracts. That is, there could be work on the impact of specific measures (e.g., cover cropping) on specific pollutants other than the ones selected but they will not be reported as 'water quality'. We attempt to mitigate this limitation by using the snowball technique where key references are traced as well as randomly reading additional papers. Nonetheless, we admit there is the possibility that we missed a few key papers.

Like all narrative and vote counting reviews, this research was unable to determine the overall magnitude (and statistical significance) of the relationship between the constructs as well as the cause of discrepancy in results of the different primary studies [68]. The method allows for the identification of potential factors (e.g., methods) responsible for the discrepancy in results of the various primary studies, however does not enable the determination or confirmation of statistical significance. Therefore, while we encourage more primary research on the topic, it is important that future reviews employ meta-analytic techniques to determine overall magnitude of the relationship between awareness, behavioural change and water quality as well as the bases of variation in outcomes reported across studies [68].

\section{Concluding Remarks}

Diffuse water pollution from agriculture (DWPA) is a major and persistent environmental issue worldwide causing multiple problems. Recent policies introduced to improve water quality have focused on raising land managers' awareness regarding diffuse pollution, under the expectation that this would influence behaviours and thus increase uptake of best management practices. As stakeholders commit financial resources to awareness-focused approaches, it is important that a good understanding of the awareness-behavioural change-water quality pathway is developed to assess the effects of these policy interventions. In this study, we systematically review, for the first time, the evidence across the full pathway drawing on published peer-reviewed papers from both the social and natural sciences.

Results indicate that there is no study that looks at the pathway in full, showing the paucity of research on the topic. For the existing studies that focused on the different components of the pathway, we find mixed evidence for the relationship between awareness and behaviour, and behavioural change and water quality; some studies reported negative relationships, others found positive relationships, 
yet other studies reported that no impact on behaviour and water quality was found despite the implementation of awareness-focused interventions. Furthermore, complexity within the pathway has hardly been addressed by the literature. Complexity and variability of diffuse water pollution, catchments and pro-environmental behaviour challenge our ability to design 'tailored' diffuse water pollution reduction measures. However, from a research perspective, a better understanding of the factors that mediate or moderate the relationships between the various components of the pathway might enable us to disentangle the mechanisms through which these relationships operate as well as the conditions under which they occur. Such a more profound understanding would offer an opportunity to design and implement more context-specific, and possibly more effective policies to influence uptake of BMPs and ultimately improve water quality. This could be facilitated through the development of an integrative model, in which researchers treat behavioural change as a key mediator in the relationship between awareness and water quality, with other situational, biophysical and psychosocial factors acting as moderators of these relationships across the awareness-behaviour-water quality pathway.

From a policy perspective, policymakers need to incorporate the relevant factors outlined in the full pathway in their strategies to influence uptake of mitigation measures. The outcomes and impacts of such strategies on behaviour and water quality could then be evaluated using the integrative models developed from research. While the implementation of such integrative models could be challenging, their application could offer very useful understandings of the role of DWPA policies.

Author Contributions: This research was conceived by M.O., with the guidance of P.J.C., J.M.-O. and P.N. Data extraction, formal analysis, interpretation of results, and preparation of original draft were carried out by M.O. under the supervision of P.J.C., J.M.-O. and P.N. All authors contributed to revisions and improvement of the write up of the paper.

Funding: This research was funded by the University of Leeds International Doctoral Scholarship (LIDS) (2017-2020).

Acknowledgments: Authors are grateful to Rachael Carrie, Marie Ferre, Lina Brand Correa, Rachel Palfrey and Edna Dualeh from the School of Earth and Environment, University of Leeds.

Conflicts of Interest: The authors declare no conflict of interest.

\section{Appendix A. Application of search terms}

\section{Awareness-behaviour link:}

Search terms applied covered terms in group 1, 2 and 3: e.g.,

Knowledge PLUS implement* PLUS farm practice* (using * to capture the fullness of the topic, and "AND" to enhance relevance of returned outputs).

\section{Awareness-water quality link:}

Search terms applied covered terms in group 1, and 4: e.g.,

Knowledge PLUS water quality improvement* (using * to capture the fullness of the topic, and "AND" and "OR" enhance relevance of returned outputs and, also capture papers that included knowledge and any of the environmental outcomes under consideration).

\section{Behaviour-water quality link:}

Search terms applied covered terms in group 2, 3 and 4: e.g., Adopt* PLUS diffuse pollution mitigation measure* PLUS water quality improvement (using * to capture the fullness of the topic, and "AND" and "OR" enhance relevance of returned outputs and, also capture papers that included knowledge and any of the environmental outcomes under consideration)

Finally, an overall search was run to cover all groups (1-4). Combinations of all these was done systematically for all search terms under each of the groups. The final process in literature search involved a snowball technique of manually tracing references from key papers such as $[8,9,26]$. 


\section{Appendix B}

Table A1. List of Final Papers Used for the Evidence Review.

\begin{tabular}{|c|c|c|c|}
\hline Study & Title & Location & Journal \\
\hline [9] & The effectiveness of agricultural stewardship for improving water quality at the catchment scale: Experiences from an NVZ and ECSFDI watershed & United Kingdom & Journal of Hydrology ** \\
\hline [32] & $\begin{array}{l}\text { Environmental Stewardship in UK Agriculture: A Comparison of the Environmentally Sensitive Area Programme and the Countryside Stewardship } \\
\text { Scheme in South East England }\end{array}$ & United Kingdom & Geoforum * \\
\hline [33] & Farmer perspectives and practices regarding water pollution control programmes in Scotland & United Kingdom & Agricultural Water Management * \\
\hline [62] & $\begin{array}{l}\text { Monitoring catchment scale agricultural pollution in Norway: policy instruments, implementation of mitigation methods and trends in nutrient and } \\
\text { sediment losses }\end{array}$ & Norway & Environmental Science \& Policy *** \\
\hline [58] & Effectiveness of buffer strips in removing pollutants in runoff from a cultivated field in North-East Italy & Italy & Agriculture, Ecosystems \& Environment $* * *$ \\
\hline [63] & Contributing understanding of mitigation options for phosphorus and sediment to a review of the efficacy of contemporary agricultural stewardship measures & United Kingdom & Agricultural Systems $* *$ \\
\hline [23] & Generating applicable environmental knowledge among farmers: experiences from two regions in Poland & Poland & Agroecology and Sustainable Food Systems * \\
\hline [37] & Toward a theory of farmer conservation attitudes: Dual interests and willingness to take action to protect water quality & United States & Journal of Environmental Psychology* \\
\hline [59] & $\begin{array}{l}\text { Assessing the impacts of Best Management Practices on nitrate pollution in an agricultural dominated lowland catchment considering environmental } \\
\text { protection versus economic development }\end{array}$ & Germany & Journal of Environmental Management *** \\
\hline [22] & Awareness and pro-active adoption of surface water BMPs & United States & Journal of Environmental Management *** \\
\hline [57] & Environmental cross-compliance mitigates nitrogen and phosphorus pollution from Swiss agriculture & Switzerland & European Journal of Agronomy ** \\
\hline [21] & Monitoring of diffuse pollution from agriculture to support implementation of the WFD and the Nitrate Directive in Estonia & Estonia & Environmental Science \& Policy *** \\
\hline [47] & Catchment scale risk-mitigation experiences- key issues for reducing pesticide transport to surface waters & Sweden & British Crop Protection Council Symposium Proceedings ** \\
\hline [61] & The effectiveness of nitrate vulnerable zones for limiting surface water nitrate concentrations & United Kingdom & Journal of Hydrology ** \\
\hline [60] & Effects of lowering nitrogen and phosphorus surpluses in agriculture on the quality of groundwater and surface water in the Netherlands & Netherlands & Journal of Hydrology ** \\
\hline [46] & Identifying and understanding factors influencing the uptake of new technologies on dairy farms in SW England using the theory of reasoned action & United Kingdom & Agricultural Systems ** \\
\hline [46] & Measuring and understanding agricultural producers' adoption of nutrient best management practices & United States & Journal of Soil and Water Conservation ** \\
\hline [34] & Adopting sustainable farm management practices within a Nitrate Vulnerable Zone in Scotland: The view from the farm & United Kingdom & Agriculture, ecosystems \& environment $* * *$ \\
\hline [11] & Effects of awareness on farmers' compliance with diffuse pollution mitigation measures: a conditional process modelling & United Kingdom & Land Use Policy *** \\
\hline
\end{tabular}

Notes: ${ }^{*}=$ Social science focused; $* *$ Natural Science focused; $* * *$ Cuts across the social and natural sciences 
Table A2. Summary of variables affecting the awareness-behavioural change-water quality pathway.

\begin{tabular}{|c|c|c|c|c|c|c|c|c|c|c|c|c|c|c|c|c|c|c|c|c|c|c|c|c|c|c|c|}
\hline Categories: Focus of Study & Study & 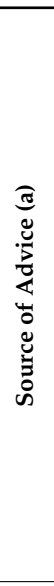 & 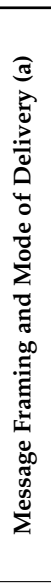 & 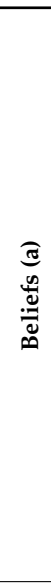 & 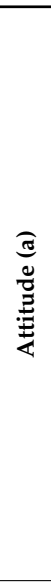 & 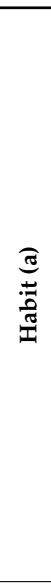 & 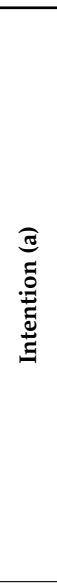 & 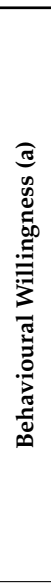 & 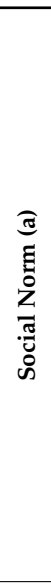 & 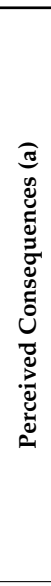 & 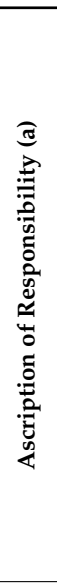 & 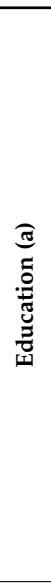 & 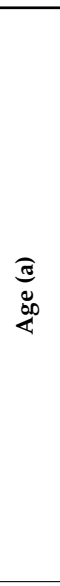 & 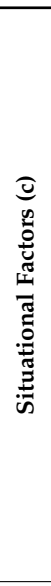 & 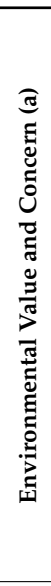 & 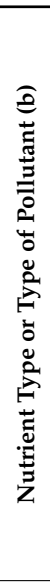 & 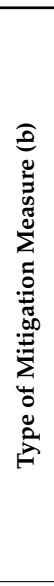 & 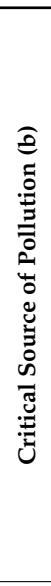 & 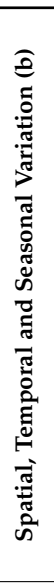 & 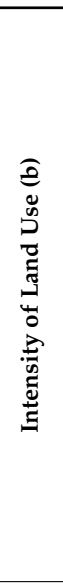 & 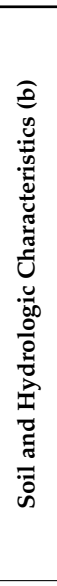 & 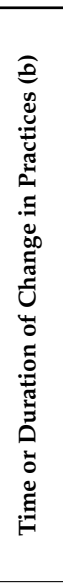 & 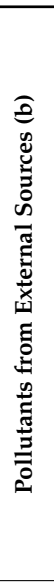 & 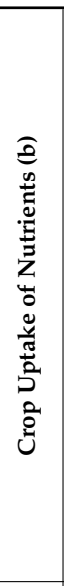 & 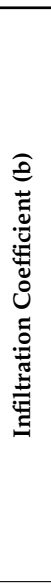 & 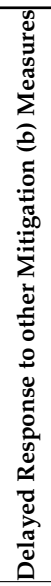 & 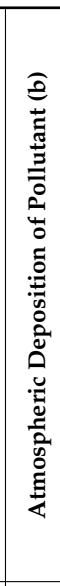 \\
\hline \multirow{8}{*}{ Awareness and behavioural change link } & $\begin{array}{l}322] \\
\end{array}$ & & & & $\mathrm{x}$ & & & & $\mathrm{x}$ & $\mathrm{x}$ & & & $\mathrm{x}$ & & $\mathrm{x}$ & & & & & & & & & & & & \\
\hline & {$[37]$} & & & $\mathrm{x}$ & & & & $\mathrm{x}$ & & & & & & $\mathrm{x}$ & & & & & & & & & & & & & \\
\hline & [22] & & & & & & & & & & & $\mathrm{x}$ & & $\mathrm{x}$ & & & & & & & & & & & & & \\
\hline & [46] & $\mathrm{x}$ & & & & & & & & & & & & $\mathrm{x}$ & & & & & & & & & & & & & \\
\hline & [33] & & $\mathrm{x}$ & $\mathrm{x}$ & $\mathrm{x}$ & $\mathrm{x}$ & & & & & & & & $\mathrm{x}$ & & & & & & & & & & & & & \\
\hline & [34] & & & $\mathrm{x}$ & $\mathrm{x}$ & $\mathrm{x}$ & & & & $\mathrm{x}$ & $\mathrm{x}$ & & & $\mathrm{x}$ & & & & & & & & & & & & & \\
\hline & [23] & $\mathrm{x}$ & $\mathrm{x}$ & $\mathrm{x}$ & $\mathrm{x}$ & & & & & & & & & $\mathrm{x}$ & & & & & & & & & & & & & \\
\hline & [11] & & & & & & & & & & & & & $\mathrm{x}$ & $\mathrm{x}$ & & & & & & & & & & & & \\
\hline Awareness and water quality link & [47] & $\mathrm{x}$ & $\mathrm{x}$ & & & & & $\mathrm{x}$ & & & & & & & & & $\mathrm{x}$ & & & & & & & & & & \\
\hline \multirow{9}{*}{ Behavioural change and water quality link } & [58] & & & & & & & & & & & & & $\mathrm{x}$ & & & & & $\mathrm{x}$ & & $\mathrm{x}$ & & & & $\mathrm{x}$ & & \\
\hline & [63] & & & & & & & & & & & & & $\mathrm{x}$ & & $\mathrm{x}$ & $\mathrm{x}$ & & $\mathrm{x}$ & & & & & & & & \\
\hline & [59] & & & & & & & & & & & & & $\mathrm{x}$ & & & & & & $\mathrm{x}$ & & $\mathrm{x}$ & & & & & \\
\hline & [60] & & & & & & & & & & & & & $\mathrm{x}$ & & $\mathrm{x}$ & $\mathrm{x}$ & $\mathrm{x}$ & $\mathrm{x}$ & $\mathrm{x}$ & & $\mathrm{x}$ & $\mathrm{x}$ & $\mathrm{x}$ & & & \\
\hline & [62] & & & & & & & & & & & & & $\mathrm{x}$ & & & $x$ & & & $\mathrm{x}$ & $\mathrm{x}$ & & & & & & \\
\hline & [9] & & & & & & & & & & & & & $\mathrm{x}$ & & $\mathrm{x}$ & & $\mathrm{x}$ & $\mathrm{x}$ & $\mathrm{x}$ & & & $\mathrm{x}$ & & & $\mathrm{x}$ & \\
\hline & [21] & & & & & & & & & & & & & $\mathrm{x}$ & & & & & & $\mathrm{x}$ & $\mathrm{x}$ & & & & & & \\
\hline & [63] & & $\mathrm{x}$ & & & & & & & & & & & $\mathrm{x}$ & & $\mathrm{x}$ & $\mathrm{x}$ & & & $\mathrm{x}$ & $\mathrm{x}$ & $\mathrm{x}$ & & $\mathrm{x}$ & & $\mathrm{x}$ & \\
\hline & [57] & & & & & & & & & & & & & $\mathrm{x}$ & & $\mathrm{x}$ & $\mathrm{x}$ & & & $x$ & & & & & & & $\mathrm{x}$ \\
\hline Number of studies reporting variable & & 4 & 5 & 5 & 4 & 2 & 1 & 2 & 1 & 3 & 2 & 1 & 1 & 17 & 2 & 6 & 7 & 3 & 4 & 7 & 5 & 3 & 3 & 3 & 1 & 3 & 1 \\
\hline
\end{tabular}

Notes: $\mathrm{x}=$ reported in the study; Letters in parenthesis: $\mathrm{a}=$ factors directly affecting awareness and behaviour; $\mathrm{b}=$ factors directly affecting water quality; $\mathrm{c}=$ factor affecting awareness,

behaviour and water quality. 


\section{References}

1. Hutchins, M.G. What impact might mitigation of diffuse nitrate pollution have on river water quality in a rural catchment? J. Environ. Manag. 2012, 109, 19-26. [CrossRef] [PubMed]

2. OECD. Water Quality and Agriculture: Meeting the Policy Challenge; OECD Studies on Water; Organisation for Economic Co-Operation and Development: Paris, France, 2012.

3. United Nations World Water Assessment Programme. The United Nations World Water Development Report 2015: Water for a Sustainable World; United Nations Educational, Scientific and Cultural Organization: Paris, France, 2015.

4. Novotny, V. Diffuse pollution from agriculture-A worldwide outlook. Water Sci. Technol. 2013, 39, 1-13. [CrossRef]

5. Blackstock, K.L.; Ingram, J.; Burton, R.; Brown, K.M.; Slee, B. Understanding and influencing behaviour change by farmers to improve water quality. Sci. Total Environ. 2010, 408, 5631-5638. [CrossRef] [PubMed]

6. De Moura, E.G.; Gehring, C.; Braun, H.; Ferraz, A.D.L.; Reis, F.D.; Aguiar, A.D.F. Improving Farming Practices for Sustainable Soil Use in the Humid Tropics and Rainforest Ecosystem Health. Sustainability 2016, 8, 841. [CrossRef]

7. Vrain, E.; Lovett, A.; Noble, L.; Grant, F.; Blundell, P.; Clesby, W. Farmer Attitudes Towards Diffuse Pollution Mitigation Measures in England: A Demonstration Test Catchments Report; Department for Environment, Food \& Rural Affairs: York, UK, 2014.

8. Kay, P.; Edwards, A.C.; Foulger, M. A review of the efficacy of contemporary agricultural stewardship measures for ameliorating water pollution problems of key concern to the UK water industry. Agric. Syst. 2009, 99, 67-75. [CrossRef]

9. Kay, P.; Grayson, R.; Phillips, M.; Stanley, K.; Dodsworth, A.; Hanson, A.; Walker, A.; Foulger, M.; McDonnell, I.; Taylor, S. The effectiveness of agricultural stewardship for improving water quality at the catchment scale: Experiences from an NVZ and ECSFDI watershed. J. Hydrol. 2012, 422, 10-16. [CrossRef]

10. Merrilees, D.; Duncan, A. Review of attitudes and awareness in the agricultural industry to diffuse pollution issues. Water Sci. Technol. 2005, 51, 373-381. [CrossRef] [PubMed]

11. Okumah, M.; Martin-Ortega, J.; Novo, P. Effects of awareness on farmers' compliance with diffuse pollution mitigation measures: A conditional process modelling. Land Use Policy 2018, 76, 36-45. [CrossRef]

12. Environment Agency. Aquatic Eutrophication Management Strategy; Environment Agency: Bristol, UK, 2000.

13. Environment Agency. Catchment Sensitive Farming-ECSFDI Phase 1 \& 2 Evaluation Report; Environment Agency: Bristol, UK, 2011.

14. Environment Agency. Catchment Sensitive Farming: A Clear Solution for Farmers; Environment Agency: Bristol, UK, 2014.

15. Macleod, C.J.; Scholefield, D.; Haygarth, P.M. Integration for sustainable catchment management. Sci. Total Environ. 2007, 373, 591-602. [CrossRef]

16. OECD. Diffuse Pollution, Degraded Waters: Emerging Policy Solutions; OECD Publishing: Paris, France, 2017.

17. The Diffuse Pollution Management Advisory Group (DPMAG). Strategy to Reduce Diffuse Pollution; DPMAG: Scotland, UK, 2015.

18. Falkenmark, M. Towards integrated catchment management: Opening the paradigm locks between hydrology, ecology and policy-making. Int. J. Water Resour. Dev. 2004, 20, 275-281. [CrossRef]

19. Winfield, M.S.; Benevides, H. A Review of US Approaches to Integrated Watershed Management and Their Applicability in the Ontario Region; Pembina Institute for Appropriate Development, Environment Canada Contract: Calgary, AB, Canada, 2003; p. 405-02.

20. Iital, A.; Klõga, M.; Pihlak, M.; Pachel, K.; Zahharov, A.; Loigu, E. Nitrogen content and trends in agricultural catchments in Estonia. Agric. Ecosyst. Environ. 2014, 198, 44-53. [CrossRef]

21. Iital, A.; Pachel, K.; Deelstra, J. Monitoring of diffuse pollution from agriculture to support implementation of the WFD and the Nitrate Directive in Estonia. Environ. Sci. Policy 2008, 11, 185-193. [CrossRef]

22. Hadrich, J.C.; Van Winkle, A. Awareness and pro-active adoption of surface water BMPs. J. Environ. Manag. 2013, 127, 221-227. [CrossRef]

23. Drangert, J.O.; Kielbasa, B.; Ulen, B.; Tonderski, K.S.; Tonderski, A. Generating applicable environmental knowledge among farmers: Experiences from two regions in Poland. Agroecol. Sustain. Food Syst. 2017, 41, 671-690. [CrossRef] 
24. Baumgart-Getz, A.; Prokopy, L.S.; Floress, K. Why farmers adopt best management practice in the United States: A meta-analysis of the adoption literature. J. Environ. Manag. 2012, 96, 17-25. [CrossRef] [PubMed]

25. Steg, L.; Vlek, C. Encouraging pro-environmental behaviour: An integrative review and research agenda. J. Environ. Psychol. 2009, 29, 309-317. [CrossRef]

26. Giri, S.; Qiu, Z. Understanding the relationship of land uses and water quality in Twenty First Century: A review. J. Environ. Manag. 2016, 173, 41-48. [CrossRef]

27. Bilotta, G.S.; Milner, A.M.; Boyd, I. On the use of systematic reviews to inform environmental policies. Environ. Sci. Policy 2014, 42, 67-77. [CrossRef]

28. Evidence, C.F.E. Guidelines for Systematic Review and Evidence Synthesis in Environmental Management; Centre for Evidence-Based Conservation: Bangor, UK, 2013.

29. EC. Council Directive 2000/60/EC Establishing a Framework for Community Action in the Field of Water Policy, OJ L327; European Commission: Brussels, Belgium, 2000.

30. EC. Council Directive 91/676/EEC Concerning the Protection of Waters Against Pollution by Nitrates from Agricultural Sources, OJ L375; European Commission: Brussels, Belgium, 1991.

31. Kyllmar, K.; Forsberg, L.S.; Andersson, S.; Mårtensson, K. Small agricultural monitoring catchments in Sweden representing environmental impact. Agric. Ecosyst. Environ. 2014, 198, 25-35. [CrossRef]

32. Lobley, M.; Potter, C. Environmental Stewardship in UK Agriculture: A Comparison of the Environmentally Sensitive Area Programme and the Countryside Stewardship Scheme in South East England. Geoforum 1998, 29, 413-432. [CrossRef]

33. Barnes, A.P.; Willock, J.; Hall, C.; Toma, L. Farmer perspectives and practices regarding water pollution control programmes in Scotland. Agric. Water Manag. 2009, 96, 1715-1722. [CrossRef]

34. Macgregor, C.J.; Warren, C.R. Adopting sustainable farm management practices within a Nitrate Vulnerable Zone in Scotland: The view from the farm. Agric. Ecosyst. Environ. 2006, 113, 108-119. [CrossRef]

35. Chen, B.H.; Chang, S.X.; Lam, S.K.; Erisman, J.W.; Gu, B.J. Land use mediates riverine nitrogen export under the dominant influence of human activities. Environ. Res. Lett. 2017, 12, 094018. [CrossRef]

36. Carling, P.; Irvine, B.; Hill, A.; Wood, M. Reducing sediment inputs to Scottish streams: A review of the efficacy of soil conservation practices in upland forestry. Sci. Total Environ. 2001, 265, 209-227. [CrossRef]

37. Floress, K.; de Jalon, S.G.; Church, S.P.; Babin, N.; Ulrich-Schad, J.D.; Prokopy, L.S. Toward a theory of farmer conservation attitudes: Dual interests and willingness to take action to protect water quality. J. Environ. Psychol. 2017, 53, 73-80. [CrossRef]

38. Kollmuss, A.; Agyeman, J. Mind the Gap: Why do people act environmentally and what are the barriers to pro-environmental behavior? Environ. Educ. Res. 2002, 8, 239-260. [CrossRef]

39. Stern, P.C. New environmental theories: Toward a coherent theory of environmentally significant behavior. J. Soc. Issues 2000, 56, 407-424. [CrossRef]

40. Prager, K. Understanding Behaviour Change: How to Apply Theories of Behaviour Change to SEWeb and Related Public Engagement Activities; Scottish Government/Scottish Environment Protection Agency (SEPA): Aberdeen, UK; Edinburg, TX, USA, 2012.

41. Juntti, M.; Potter, C. Interpreting and Reinterpreting Agri-Environmental Policy:Communication, Trust and Knowledge in the Implementation Process. Sociol. Rural. 2002, 42, 216-232. [CrossRef]

42. Vrain, E.; Lovett, A. The roles of farm advisors in the uptake of measures for the mitigation of diffuse water pollution. Land Use Policy 2016, 54, 413-422. [CrossRef]

43. Kuhfuss, L.; Préget, R.; Thoyer, S.; Hanley, N.; Le Coent, P.; Désolé, M. Nudges, social norms, and permanence in agri-environmental schemes. Land Econ. 2016, 92, 641-655. [CrossRef]

44. Ayer, H.W. Grass roots collective action: Agricultural opportunities. J. Agric. Resour. Econ. 1997, $22,1-11$.

45. Rehman, T.; McKemey, K.; Yates, C.M.; Cooke, R.J.; Garforth, C.J.; Tranter, R.B.; Park, J.R.; Dorward, P.T. Identifying and understanding factors influencing the uptake of new technologies on dairy farms in SW England using the theory of reasoned action. Agric. Syst. 2007, 94, 281-293. [CrossRef]

46. Ulrich-Schad, J.D.; de Jalon, S.G.; Babin, N.; Pape, A.; Prokopy, L.S. Measuring and understanding agricultural producers' adoption of nutrient best management practices. J. Soil Water Conserv. 2017, 72, 506-518. [CrossRef] 
47. Kreuger, J.; Nilsson, E. Catchment scale risk-mitigation experiences-key issues for reducing pesticide transport to surface waters. In Proceedings of the British Crop Protection Council Symposium; pp. 319-324. Available online: https:/ / www.slu.se/globalassets/ew/org/centrb/ckb/publikationer/bcpc_symposium_ 78.pdf (accessed on 24 December 2018).

48. Stålnacke, P.; Grimvall, A.; Libiseller, C.; Laznik, M.; Kokorite, I. Trends in nutrient concentrations in Latvian rivers and the response to the dramatic change in agriculture. J. Hydrol. 2003, 283, 184-205. [CrossRef]

49. Grimvall, A.; Stålnacke, P.; Tonderski, A. Time scales of nutrient losses from land to sea-A European perspective. Ecol. Eng. 2000, 14, 363-371. [CrossRef]

50. Meals, D.W.; Dressing, S.A.; Davenport, T.E. Lag time in water quality response to best management practices: A review. J. Environ. Qual. 2010, 39, 85-96. [CrossRef]

51. Price, P.N.; Shepherd, M.; Whitehead, J.; Goodlass, G.; Anthony, S. Initial Evaluation of Effectiveness of Measures to Mitigate Diffuse Rural Pollution; Scottish Government: Edinburg, TX, USA, 2008.

52. Kyllmar, K.; Bechmann, M.; Deelstra, J.; Iital, A.; Blicher-Mathiesen, G.; Jansons, V.; Koskiaho, J.; Povilaitis, A. Long-term monitoring of nutrient losses from agricultural catchments in the Nordic-Baltic region-A discussion of methods, uncertainties and future needs. Agric. Ecosyst. Environ. 2014, 198, 4-12. [CrossRef]

53. Lord, E.; Shepherd, M.; Silgram, M.; Goodlass, G.; Gooday, R.; Anthony, S.G.; Davison, P.S.; Hodgkinson, R. Investigating the Effectiveness of NVZ Action Programme Measures: Development of a Strategy for England; Department for Environment, Food and Rural Affairs: Bristol, UK, 2007.

54. Ryberg, K.R.; Blomquist, J.D.; Sprague, L.A.; Sekellick, A.J.; Keisman, J. Modeling drivers of phosphorus loads in Chesapeake Bay tributaries and inferences about long-term change. Sci. Total Environ. 2018, 616-617, 1423-1430. [CrossRef] [PubMed]

55. Povilaitis, A. Impact of agriculture decline on nitrogen and phosphorus loads in Lithuanian rivers. Ekologija 2006, 1, 32-39.

56. Thompson, J.; Cassidy, R.; Doody, D.G.; Flynn, R. Predicting critical source areas of sediment in headwater catchments. Agric. Ecosyst. Environ. 2013, 179, 41-52. [CrossRef]

57. Herzog, F.; Prasuhn, V.; Spiess, E.; Richner, W. Environmental cross-compliance mitigates nitrogen and phosphorus pollution from Swiss agriculture. Environ. Sci. Policy 2008, 11, 655-668. [CrossRef]

58. Borin, M.; Vianello, M.; Morari, F.; Zanin, G. Effectiveness of buffer strips in removing pollutants in runoff from a cultivated field in North-East Italy. Agric. Ecosyst. Environ. 2005, 105, 101-114. [CrossRef]

59. Haas, M.B.; Guse, B.; Fohrer, N. Assessing the impacts of Best Management Practices on nitrate pollution in an agricultural dominated lowland catchment considering environmental protection versus economic development. J. Environ. Manag. 2017, 196, 347-364. [CrossRef] [PubMed]

60. Oenema, O.; van Liere, L.; Schoumans, O. Effects of lowering nitrogen and phosphorus surpluses in agriculture on the quality of groundwater and surface water in the Netherlands. J. Hydrol. 2005, 304, 289-301. [CrossRef]

61. Worrall, F.; Spencer, E.; Burt, T. The effectiveness of nitrate vulnerable zones for limiting surface water nitrate concentrations. J. Hydrol. 2009, 370, 21-28. [CrossRef]

62. Bechmann, M.; Deelstra, J.; Stålnacke, P.; Eggestad, H.; Øygarden, L.; Pengerud, A. Monitoring catchment scale agricultural pollution in Norway: Policy instruments, implementation of mitigation methods and trends in nutrient and sediment losses. Environ. Sci. Policy 2008, 11, 102-114. [CrossRef]

63. Deasy, C.; Quinton, J.N.; Silgram, M.; Bailey, A.P.; Jackson, B.; Stevens, C.J. Contributing understanding of mitigation options for phosphorus and sediment to a review of the efficacy of contemporary agricultural stewardship measures. Agric. Syst. 2010, 103, 105-109. [CrossRef]

64. Amponsah, O.; Hakan, V.; Schou, T.W.; Braimah, I.; Abaidoo, R.C. The impact of farmers' participation in field trials in creating awareness and stimulating compliance with the World Health Organization's farm-based multiple-barrier approach. Environ. Dev. Sustain. 2016, 18, 1059-1079. [CrossRef]

65. Kagoya, S.; Paudel, K.P.; Daniel, N.L. Awareness and Adoption of Soil and Water Conservation Technologies in a Developing Country: A Case of Nabajuzi Watershed in Central Uganda. Environ. Manag. 2018, 61, 188-196. [CrossRef] [PubMed]

66. Mango, N.; Makate, C.; Tamene, L.; Mponela, P.; Ndengu, G. Awareness and adoption of land, soil and water conservation practices in the Chinyanja Triangle, Southern Africa. Int. Soil Water Conserv. Res. 2017, 5, 122-129. [CrossRef] 
67. Jaffe, R.; Cowell, J.M. Approches for improving literature review methods. J. Sch. Nurs. 2014, 30, $236-239$. [CrossRef] [PubMed]

68. Koricheva, J.; Gurevitch, J. Place of Meta-analysis among other methods of research synthesis In Handbook of Meta-Analysis in Ecology and Evolution; Koricheva, J., Gurevitch, J., Mengersen, K., Eds.; Princeton University Press: Princeton, NJ, USA; Oxford, MS, USA, 2013. 